Elia Marinova*

\title{
The Post-Classical Use of Latin in Bulgaria
}

DOI: http://dx.doi.org/10.12775/LC.2019.047

\begin{abstract}
The article summarizes the evidence about the use of Latin in Bulgaria during the Middle Ages and the early modern period and comments the reasons for the lack of knowledge or the indifference to the literary tradition of the Latin West till the end of the nineteenth century. Beginning with the transformation of the Roman world in the Late Antiquity, the post-classical fate of Latinitas in the Bulgarian lands tells us for the most part a story about cut threads, periods of forced isolation from the Latin West (the spread of humanism and the access to the great achievements of the following cultural epochs in Europe were blocked by the Turkish invasion in 1396), and reconsidered confessional and political choices. My intention, however, is to present the few separate channels of transmitting Latin language and literary culture to the educated élite in Bulgaria, i.e. the diplomatic contacts with the Papacy and the European rulers, the direct or indirect translations from Latin sources, and the original works written in Latin by the Bulgarian Catholics in the seventeenth century. In these times, and later, indirect translations dominated, it was only in 1873 that the first major direct translation of a Latin text into Bulgarian appeared.
\end{abstract}

Keywords: Greek and Latin in the East Balkans, Latin in medieval Bulgaria, Latin works of the Bulgarian Catholics

\section{Poklasyczna obecność łaciny w Bułgarii}

Streszczenie: Artykuł prezentuje świadectwa na temat obecności łaciny w Bułgarii w wiekach średnich i we wczesnej nowoży tności oraz omawia przyczyny braku wiedzy lub zainteresowania literacką tradycją łacińskiego Zachodu aż do końca XIX wieku. Wraz z początkiem przemian świata rzymskie-

\footnotetext{
* Associate Professor for Latin language and literature in the Department of Classical Philology, Faculty of Classical and Modern Philologies, Sofia University "St. Kliment Ohridski". Her research interests are focused on Roman Literature, Medieval Latin Literature and Neo-Latin Studies.

E-mail: e.marinova@uni-sofia.bg | ORCID: 0000-0001-5645-6363.
} 
go w późnym antyku los poklasycznej Latinitas na terenach Bułgarii wskazuje na przecięcie wątków, na czas wymuszonej izolacji od łacińskiego Zachodu (rozprzestrzenianie się humanizmu i dostęp do wielkich osiągnięć kolejnych epok kultury europejskiej został zablokowany przez turecką inwazję w 1396 r.) i zmienionych wyborów religijnych oraz politycznych. Moim zamiarem jest jednak przedstawienie kilku osobnych sposobów przepływu języka lacińskiego i kultury literackiej do wykształconych elit w Bułgarii, związanych z kontaktami dyplomatycznymi z papiestwem i władcami europejskimi, bezpośrednimi i pośrednimi tłumaczeniami źródeł łacińskich, a także oryginalnymi dziełami pisanymi po łacinie przez bułgarskich katolików w XVII wieku. W tym czasie, i później, dominowały przekłady pośrednie, pierwsze dłuższe bezpośrednie tłumaczenie łacińskiego tekstu na bułgarski pojawiło się dopiero w roku 1873.

Słowa kluczowe: greka i łacina na Bałkanach Wschodnich, łacina w średniowiecznej Bułgarii, łacińskie pisma bułgarskich katolików

\section{Introduction}

f we presume that Latinitas is in the first place the ability of reading, writing and speaking correct and clear Latin, its importance for the educational system and the intellectual life in the medieval Bulgarian state would be negligibly small. Bulgarian literary culture - basically because of the geographical location and the historical fate of the land - has never been defined by the use of Latin; it was the Greek that was indisputably dominant in all periods of the Bulgarian history till the second half of the nineteenth century. In contrast with the Western Balkans, which remained deeply entrenched in the Latin tradition, Latinitas in medieval and early modern Bulgaria never developed to a rhetorical concept or to a topic of a public dispute about the advantages of Latin vs. vernacular. This part was to be played by Greek literacy, and from the end of the nineteenth century - by modern European languages and literatures which transmitted to the emerging Bulgarian intellectual élite the most important ancient linguistic theories, and - four centuries after their birth in West Europe - the humanistic concepts of language and style.

For that reason, any attempt to present the post-classical legacy of Latin in Bulgaria would necessarily take the appearance of a short apophatic account: Latin has never been a subject of teaching (not to mention a language of teaching) in the Bulgarian schools till the beginning of the twentieth century ${ }^{1}$; it was at that period again that the first direct translations from Latin in Bulgarian appeared ${ }^{2}$; before that readers got familiar with Latin authors via Croatian, French, Italian and Russian translations. Since expertise in language was decisive for the appropriation of the Latin literature, it is comprehensible that original works in Latin have barely been produced within the frontiers of the Bulgarian lands. The only

\footnotetext{
1 A few exceptions were some Catholic enclaves in Northern Bulgaria in the middle of the 17th century like the schools in Chiprovtsi and Trančovica, where Latin was taught at the introductory level.

2 The first ancient Latin work, which appeared in 1911 in a full-length Bulgarian translation, was Vergil's Aeneis (rendered in a rough Bulgarian paraphrase by the Bishop of Skopje, Theodosius).
} 
texts composed in Latin were created abroad, by Bulgarians who lived out of the country, except for the missionary writings of the Bulgarian Catholics in the seventeenth century.

The circumstances changed significantly after the liberation of Bulgaria from Ottoman rule (1878) and the foundation of the Higher Paedagogical School (the future Sofia University "St. Kliment Ohridski") in 1888, and the establishment of a Chair for Classical Philology in 1921. Greek and Latin entered the program in the classical schools and remained compulsory subjects till 1944. Unfortunately, in the following decades of totalitarian régime they were removed from the contents of the secondary education, but in 1977 the broken tradition revived with opening the National Gymnasium for Ancient Languages and Culture "Saint Constantine-Cyril the Philosopher". Classical scholars educated in France, Italy and Germany wrote sometimes in Latin, to number only Georgi Kazarov, De foederis Phocensium institutis (Leipzig, 1898), the critical Teubner edition of Excerpta Valesiana, initially edited by Jacques Moreau and then revised by Velizar Velkov in 1968, and the most important scholarly achievements of Boris Gerov, who edited Inscriptiones Latinae in Bulgaria repertae (Sofia, 1989), and of Georgi Mihailov, Inscriptiones Graecae in Bulgaria repertae, 5 vols. (Sofia, 1958-1997). In spite of this, the disproportion between the amount of literature translated from Greek and the modest share of the Roman tradition, which was mainly represented by fragments from Cicero, Sallust and the Augustan poetry, disappeared only in the years between the First and the Second World War, when for a first time the number of translations from Latin came up with the traditionally prevailing number of the Greek ones $^{3}$. In the 1980s, which registered a peak both in the translation activity and the public demand for masterpieces of the world classics, many neglected or partly known Roman authors were introduced to the wider audience. As a logical continuation of this process of filling the gaps and compensating the losses, from the 1990s and through the following decades appeared the first Bulgarian translations of Latin Patristic, and the focus on Latinity shifted to some extent from the Classical Antiquity to the Medieval and the Neo-Latin literature. St. Augustine, St. Cyprian, Thomas of Aquino and Marsilio Ficino entered the Bulgarian libraries in modern annotated translations.

Back to the medieval times, we can say that the fate of Latinitas in the Bulgarian lands presented for the most part a story about cut threads, reconsidered confessional and political choices, and almost five-centuries-long forced isolation from the cultural processes in Europe. And yet, this story is worth to be told, since it explains a lot about the formation of specific attitudes to education, rhetorical culture and concepts of style in the early modern Bulgarian society. There is a lot of scholarly literature examining the influence of Byzantium both on the political and cultural growth of its neighbor tsardom. The interaction of the Bulgarian society with medieval and modern Europe, on the other side, has mainly been discussed in its political dimension as a process of diplomatic negotiations and institutional communication with no bearing on the literary culture in Bulgaria. As a consequence, scholars approach the body of Latin medieval texts related to Bulgaria as sources illustrating the complex relations between the Bulgarian rulers, the Byzantine Empire and the Latin West, but ignore or even reject as irrelevant the question about possible Latin influences upon the Bulgarian literary culture.

\footnotetext{
3 The history of the translations of classical literature in Bulgaria in the end of the nineteenth and the twentieth century is a topic of a special volume, edited by Anna Nikolova (2002).
} 


\section{Latin in Medieval Bulgaria $\left(7^{\text {th }}-14^{\text {th }} c\right.$.}

Some early preconditions for the total yielding of Latin from the East Balkans may be found in the linguistic situation in the Roman provinces that partially overlap with the territory of contemporary Bulgaria. Hellenized Thrace had for official language the Greek; the knowledge of spoken Greek and the spread of Greek literacy exceeded significantly those of Latin. In Moesia Inferior, on the other side, Latin, although being the official language of the administration, and even more importantly, of the legionaries recruited from different parts of the Roman Empire, had nonetheless to maintain its status of prestige in a steady competition with Greek (as a spoken idiom and as the language of a significant amount of Greek inscriptions from Lower Moesia). After that Constantine moved in 330 the capital of the Empire to Constantinople, Latin speakers at first benefited from the spread of Latin administrative vocabulary; in a long-term perspective, however, this act determined the future end of Latin in these lands, since Constantine's decision transformed the East Balkans from a periphery of Rome to a hinterland of the capital of the Eastern Roman Empire. The next important change occurred in the sixth and early seventh centuries, as masses of Slavs settled down in the Balkan Peninsula and Byzantium lost the limes on Danube. The withdrawal of the administration and of the imperial armies from the Balkans left behind a completely transformed Roman world to be found by the Proto-Bulgarians invading the North-Eastern Balkans in the seventh century. Subsequently two factors proved to be of vital importance for the direction to be taken by the future Bulgarian state and its multiethnic society - the close proximity to the gravitation nucleus of Byzantium and the triumph of the Orthodox Christianity as a means for the cultural assimilation of Slavs and Bulgarians.

In this way, in spite of the high number of romanized population and the amount of Latin inscriptions including those dating from the fourth to sixth century in the lands of the diocese Thracia, the ashes of Romanitas in these lands never had to give birth to the phoenix of Latinitas. To name only the most obvious reason, in the south of the founded in the last quarter of the seventh century First Bulgarian State, the inheritors of the Roman Empire did not speak Latin but Greek.

The knowledge of Latin in medieval Bulgaria is still a blank space in the pages of the histories of Bulgaria. In the scholarly literature there are only speculations about the use of Latin as a language of the clergymen and the nobility during the periods of close relations between Rome and the Bulgarian Empire. Even in these periods, when worries about the impending political and cultural assimilation by the Byzantine Empire set the country in a Western course, the knowledge of Latin barely extended beyond the palace and the circle of scholars closely connected with it.

The best indication of deficient familiarity with the Latin tradition is the choice of authors translated in Old Bulgarian. The facts are irrefutable. We can speak about continuous tradition in translating Greek Patristic and Byzantine literature beginning with the ninth century (the prolific work of the first translators in Ohrid, Pliska and Preslav) to the remarkable translation school of Tărnovo in the fourteenth century. In the same time, the only textual evidence for some vague acquaintance with Latin authors is the Simeon's Miscellany (Svetoslavov izbornik of 1073), based on a Byzantine anthology of popular texts which included as chapters 435-436 a fragment from De nativitate of Irinaeus of Lyon, and 
another excerpt from The dogmatical works of St. Augustine (the title is not specified by the compiler), discussing the nature of the St. Trinity (Spasitelna kniga 2008: 362-363). The same conclusion can be made about the original works written in Old Bulgarian that reached West Europe in a Latin translation. The best known example is an apocryphe, written by an anonymous author in the tenth century, which became popular among the Patarene and the Cathar communities in Italy and France under the name Secretum or Interrogatio Johannis. Unfortunately, the Old Bulgarian original, which would be the most important document of the dualistic heresy of the Bogomils, is lost; the text is preserved in two slightly different Latin versions represented by three manuscripts in Vienna and Carcassonne. The colophon in the end of the Codex Carcassoniensis refers explicitly to the Bulgarian origin of the Secret book and to the fact that the head of the Cathar sect of Concorezzo, Nazarius, brought it from Bulgaria, but it does not answer the questions about the place where the text has been rendered into Latin and the personality of the translator: "Hoc est secretum haereticorum de Concorezio portatum de Bulgaria Nazario suo episcopo, plenum erroribus" (Gjuzelev et al. 1981: 125). If we consider the remark of Anselm of Alexandria that the book was written in bad Latin "et etiam falsis Latinis" (Dondaine 1950: 319), we can conclude that the translation was made in the East, and most probably - in Constantinople 4 .

The lack of translations from Latin in medieval Bulgaria is not surprising if we keep in mind the well-known indifference of the Byzantine civilization to the literary production of the West. Indeed, beside many other political and economical changes, the Fourth Crusade brought a reconsideration of this attitude as well; the names of personalities like Juan Fernandes de Heredia and Simone Atumano and of specific centers in the Latin Empire of Constantinople like Crete are connected with noteworthy translating activities and with the arrangement of libraries including Latin manuscripts. The translations of Latin authors in Greek and the loans from the Latin tradition, however, were not as common as the translations of Greek (classical and medieval) authors in Latin, and left no imprint upon the literature or the knowledge of Latin in neighboring Bulgaria. A century later, at the time when the actual exchange of texts and ideas between Byzantium and Italy began, the Turkish occupation had already deleted the Second Bulgarian Empire from the political map of Europe.

The use of Latin as a language of diplomacy in medieval Bulgaria is another issue which puts many unsolved problems. In the first place, the astonishing deficit of interpreters from Latin in the palace in periods of most intense communication with the Papacy or with the Western kingdoms is a question to be tackled once again. We know that Greek was used as the official written language of the First Bulgarian Empire till the development of the Cyrillic alphabet by the disciples of St. Cyril and Methodius in the end of the ninth century, and the Bulgarian court kept using it in its relations with Byzantium even after that; the Bulgarian sovereigns had as a rule a good (or even excellent) command of written and spoken Greek, and the palace administration imitated certain peculiarities of the Byzantine chancellery style. But which language did they use in the dialogue with the Latin West?

\footnotetext{
4 Anselm of Alessandria apparently had access to a lost copy of Secretum and left a comment on it in his Tractatus de haereticis. According to Peter Biller (Biller 1994: 59), another explanation is that "there would have been westerners living in Constantinople in the twelfth century who were capable of translating Bogomil texts into Latin".
} 
A commonly accepted opinion (Dimitrov 1999: 111-112; Gjuzelev 2009: 330, n. 95) is that the entire paperwork went through a double version - from Bulgarian to (Byzantine) Greek and from Greek to Latin. This view is strongly supported by a textual evidence like the incipit of a letter of Tsar Kaloyan to Pope Innocent III (ca. 1200), which explicitly says that the letter has been translated from Bulgarian in Greek and subsequently from Greek in Latin: "Littere Caloiohannis domini Bulgarorum et Blachorum, misse Domino Innocentio pape III, translate de bulgarico in grecum et de Greco in latinum" (Dujčev et al. 1965: 309). A practice of this kind had its obvious shortcomings, since it could easily jeopardize the success of the diplomatic contacts. The fact that Bulgarian rulers were perfectly aware of the inefficiency of the double translation process is something that shows up in the aforesaid correspondence between Innocent III and Kaloyan. The dynamic situation on the Balkans in the beginning of the Fourth Crusade and the attempts of Kaloyan to obtain an imperial crown from the Holy See in return to the official acknowledgment of the papal supremacy demanded a lot of negotiating through letters and oral messages. Eventually, despite the disagreement of the Hungarian king, Kaloyan achieved a partial fulfillment of his aspirations, as the Pope let him be crowned as a king (but not as an emperor) of Bulgarians and Vlachs, and consecrated the head of the Bulgarian Church, Blasius (Vasilij), as a primas (instead of raising him to a patriarch). Most likely, the need of exact articulating of Kaloyan's aspirations and avoiding any misunderstandings or substitution of one title with another (Kaloyan was perfectly aware that "a primate" and "a patriarch" did not amount to the same thing) explains the consideration of the language problem in Kaloyan's letters ${ }^{5}$. In a message from November 1204 Kaloyan asked the Pope to facilitate the instruction in Latin of two Bulgarian boys he had sent to Rome: "Misi autem ad tuam magnam sanctitatem pueros duos, unus vero nominatur Basilius, alius Bithlehem. Et dentur ex praecepto eius, ut addiscant in scolis litteras Latinas, quoniam hic grammaticos non habemus, qui possint litteras, quas mittitis nobis, transferre, et postquam ipsi addiscerint, remittantur ad imperium meum" (ibid.: 359). If we look at the exact phrasing "Let they be sent to school to learn Latin, since we don't have here grammatici able to translate the letters you are sending to us", there could be no doubt that Kaloyan (being himself excellent in Greek after the years of hostage in Constantinople) was displeased or even anxious about the total dependence on the mediated translation. The use of Greek as a go-between established the (not always welcome) key role of people like the Archbishop of the Greeks in Brindisi ("Dominicus archipresbyterus Grecorum de Brundisio") in the negotiations. Besides, the complaint of Kaloyan shows that some messages from the Papal Curia might have been delivered by carriers who were not proficient in both languages - Latin and Greek or Latin and Bulgarian. For this reason, he needed trained and trustworthy interpreters in his palace, or even better, in his own family. In a letter from November 1204 the recently consecrated Head of the Bulgarian Church Blasius confirmed that the two boys had set out for Rome according to the wish of Kaloyan, and indicated who they were - the son of the priest Constantine and the son of Kaloyan himself: "Interea sciat vostra magna sanctitas, quod duos pueros ex precepto domini imperatoris vobis mitto, unus est presbyteri Constantini filius, alius vero regis, ut ex precepto vestre sanctitatis litteras Latinas addiscant et quidquid meditari valetis

\footnotetext{
5 Most certainly, the terminological discrepancy in this case is to be explained with the different political views of the Bulgarian and the Apostolic Chancery.
} 
ad honorem imperatoris, faciatis" (ibid.: 360). The potential care of the language instruction of Kaloyan's son is clearly named "an act of according due respect to the Emperor". We do not know, however, what the response of the Pope was, and we can only speculate about the likeliness of any competence in Latin of the Bulgarian primas Blasius (Vasilij). Questions like these emerge all the time: in a letter accompanying the Privilegium of the papal chancellery we read that the Pope had sent to Blasius the exact formula of the Catholic oath of consecration (iuramentum) as to be memorized by him and all his successors (obviously not in Greek, but in Latin or maybe in Bulgarian translation?), "cuius formam bulla nostra signatam ad perpetuam memoriam destinamus" (ibid.: 327); in another letter from 1203 Kaloyan insisted that every word of Blasius's report to the Pope be accepted as "a faithful rendering" of his own words, since Blasius spoke for the Bulgarian ruler. One asks himself what language Blasius spoke in the Curia and if he needed another person to translate from Greek in Latin, one may wonder how this changed the meaning of epistolary clichés like that of the "authenticity" of the message.

Strangely enough, the importance of the language question is not properly recognized in the numerous interpretations of the best-known episode in the Bulgarian history - the conversion of the Bulgarians to Christian faith. This act, as stated by many historians, was not a dramatic confessional choice (as there was still no schism between Byzantium and Rome) and certainly not a clash of two cultural orientations, but rather a choice of patronage and a matter of politics. To summarize the familiar facts, it was in the 860s, shortly after that Byzantium rejected the Iconoclasm and started to progressively extend its influence over the Balkans, when Khan Boris I appealed to the Frankish king, Louis the German, to send Frankish missionaries in Bulgaria. A defeat by the armies of the Byzantine emperor made him reconsider his plans and assume the Christianity in 864, the emperor himself being his godfather. Yet, only a year after having received the Baptism, Boris sent three delegates - Petrus, Iohannes and Martinus - to bring to Pope Nicholas I a list of Consulta, discussing along with many other practicalities the prospect of setting up an independent Bulgarian archbishopric. At the same time, he asked again Louis the German to send missionaries to Bulgaria and to provide ecclesiastical books. After the rejection by the Papacy of several proposals for the seat of the Bulgarian archbishop, Boris restored his relations with Byzantium and at the Council of Constantinople (869-870) Bulgaria was placed under the control of the Patriarchy, receiving in return its own archbishopric. In this way, the negotiations which lasted more than twenty years and covered the time of power of three popes - Pope Nicholas I, Pope Adrian II and Pope John VIII, and of two patriarchs - Photios and Ignatios, ended with the solution which - at that moment - seemed to better suit the political goals of the Bulgarian ruler.

An underestimated aspect of this intricate story is the language used for the communication with the Papacy and with the Eastern Frankish Kingdom. Scholars generally presume that Boris I had sent in Greek his questions about the obligations of the Christian ruler and the different aspects of Christian life ${ }^{6}$. The apostolic secretary and renowned polyglot, Anastasius Bibliothecarius, is usually credited with the official translation of the

\footnotetext{
${ }^{6}$ The original questions are not preserved but they can be restored from the letter of Pope Nicholas I, written in the autumn of 866 and well-known in the scholarly literature as Responsa Nicolai I. papae ad consulta Bulgarorum (Dujčev et al. 1960: 65-125).
} 
Consulta Bulgarorum in Latin. The sources which are mainly Byzantine can be interpreted one way or the other, but we would like to agree with Paul Speck (Speck 2000: 358) asking about the language of the lost Questions of the Bulgarians: "Why actually not in Latin"? Why should the original document have been written in Greek? An convincing point of Speck's argumentation is that the delegates - Petrus, Martinus and Johannes - being sent to Rome to bring the Consulta, must have been baptized in Rome (ibid.: n. 101). Let us also remind that Pope Nicholas I was familiar with the Greek idiom, but the Frankish king most certainly did not use Greek in his correspondence with Khan Boris I., and the liturgical literature that the Bishop of Passau brought to Bulgaria was hardly meant to reach the Bulgarian neophytes in Greek translation. Finally, one should try to imagine the Responsa Nicolai I. papae (especially the answers concerning the hierarchy of the Patriarchs or the Holy Communion) in Greek, and ask himself who and why might have rendered them to Greek $^{7}$. If we recall the events from 868, when Pope Adrian II, after warmly receiving St. Cyril and Methodius, consecrated the Slavic translations of the Bible and let the bishops Formosa and Gauderic celebrate a mess in Slavonic in several churches in Rome, it is much more credible that the Pope secured a Latin instruction for some Bulgarian pupils at Rome or included in the missionary of Bishop Formosa of Porto to Bulgaria persons being trained both in Latin and Slavonic. Unfortunately, the sources are insufficient, but they are clear enough to disprove the praesumption about the absence of any educated Latin speakers in the palaces of Pliska and Preslav and to refute the popular theory ${ }^{8}$ that an affiliation to the Roman Church in 870 would have stopped the development of the rich Old Bulgarian literacy in the following centuries.

\section{The Franciscan Missionaries and the Latin Historiography in Bulgaria $\left(15^{\text {th }}-17^{\text {th }} \mathrm{c}\right.$.}

In Bulgaria the spread of humanism and the access to the great achievements of the following cultural epochs in Europe were blocked by the Turkish invasion in 1396. The forthcoming five centuries were a time of almost complete oeconomical and cultural isolation from the West. Against this background speaking of whatever Bulgarian contribution to the Neo-Latin literature could seem pointless, or - to put it in the words of Jozef IJsewijn (1990: 91): "Latin never played any significant role among the Bulgarians, Macedonians, Serbians, Bosnians and other Slavs of the South and the East Balkans". This is generally true, but there are a few exceptions and they need to be put together in a coherent picture. Although scholars like Eusebius Fermendžin (1887), Ljubomir Miletič (1904) and Ivan Dujčev (1939) laid the indispensable foundations for any further study of the history of the

\footnotetext{
7 We know for certain that Anastasius was the 'dictator' of the letter of Pope Nicholas I to Boris (Nicolai I Epistolae, nr. 99, pp. 568-600); on the other hand, there is no mention of any Greek translation of the letter.

8 A survey of different evaluations of the Latin and the Byzantine attitude to the legitimacy of the Slavonic liturgy, which was to become a basic stone of Bulgarian medieval culture, in Dragova (2005: 113-114).
} 
Bulgarian Catholics, the amount of collected documents calls for a final appraisal of the use of Latin in the specific context of the literature preceding the Bulgarian Enlightenment.

This concerns in the first place the literary production of the missionaries of the Franciscan Order in the Balkans. For different historical reasons the Bosnian Franciscans were the only representatives of a Catholic institution in the Balkans recognized by the Turkish authorities. Their work in Bulgaria was most fruitful in the seventeenth century, when Bulgaria separated from Bosna Argentina, at first as a custodia (1624), and later as an independent Franciscan province (1676), and obtained two Catholic metropolitan sees - in Sofia and in Marcianopolis. Maybe the most important outcome of the missionaries' work in Northwest Bulgaria was the establishment of a school for about thirty pupils and a monastery library in Chiprovtsi, an old settlement of Saxon miners. Unfortunately, the archives burnt, when Chiprovtsi was set on fire in the great revolt of 1688 , so that any reasoning over the content of the school program or the language and the topics of the books in the Franciscan library would be speculative. According to some documents published by Borislav Primov (1993: 7-9), Latin was the official language of the liturgy in Chiprovtsi and the laymen understood it well enough as to participate in the Sunday mass. The real training, however, including the proper introduction to Latin, took place in Italy. The Sacred Congregation for the Propagation of Faith sent the best pupils to the famous Illyrian College in Loreto and to Rome. After having received an excellent education in theology, Latin and Italian, they returned home and took the lead of the movement for liberation of the Bulgarians (Filip Stanislavovič) or travelled over Europe addressing different authorities and rulers with petitions for a military or diplomatic help (Petăr Parčevič).

The most important contribution of these men who were prolific writers in Italian, Bulgarian, Illyrian and Latin, was the attempt to create a national historiography in Latin which had to meet the standards of the best contemporary models in the historical genre such as the works of Caesar Baronius, Mauro Orbini, Du Cange and Jozef Simon Asemani ${ }^{9}$. Most of these texts never came to the knowledge of the international audience, which their authors intended to address, but there could be nothing more absurd than the idea that they wrote in Latin just to show off and to put away their studies in the drawer. Books of huge importance and value as the first Bulgarian history ${ }^{10}$, written by the archbishop of Sofia, Petăr Bogdan Bakšič (=Bakšev, 1601-1674), or Historia Bulgarorum of the Croatian Jesuit Franjo Ksaver Ivan de Pejačević (1707-1781), whose parents, however, came from the Bulgarian town Chiprovtsi, remained in manuscript due to the premature death of their authors or

9 These towering figures of the sixteenth and the seventeenth centuries contributed a lot to the study of the Bulgarian history: the chronicles of Baronius, Annales ecclesiastici a Christo nato ad annum 1198 (1588-1607); the history of the South Slavs by Mauro Orbini, II Regno de gli Slavi, written in Italian in 1601 and afterwards translated in Latin; Du Cange's History of Byzance (1657) and Kalendaria ecclesiae universae of the Prefect of the Vatican library, Asemani (1755).

10 Until recently it was believed that the history of Bakšič, Historia bulgarica, survived only in an incomplete version - Ms. Vat. Borg. lat. 485, ff. 207r-21, which contained the introduction and four chapters of the original text (Dimitrov 2001: 79-81). In the autumn of 2017 a scholar team from the University of Blagoevgrad announced the discovery of an earlier and genuine version of Bakšič's History in the Library of Modena, Italy. Unfortunately, Bakšič's work has not been published so far, and we may only presume by the title Fratris Petri Deodati a Chiprovatio Ordinis minorum de Observantia Archiepiscopi Sardicensis Sophiensis nuncupati de antiquitate Paterni soli, et de rebus Bulgaricis ad suos Compatriotas and by the proclaimed volume (about 200 pages) that it would considerably change the idea of the Latin literary culture of the Bulgarian Catholics in the seventeenth century. The same can be argued about the Historia Bulgarorum of Pejačević, which was discovered in the University Library of Zagreb in 1976, but is still unpublished and inaccessible for scholarly use. 
other unfortunate circumstances, but they were certainly meant to reach as many of the educated readers in Europe as possible, and to recall the past of the Bulgarian state by using the lingua franca of the scholarly and diplomatic communication. Besides, one should have in mind that printing presses were prohibited within Bulgaria by the Turks, and authors had to publish in Belgrade, Budapest, Bucharest, Vienna and Venice. Otherwise than the first history composed in Bulgarian by Paisius of Hilendar that was copied in over 70 transcripts, and circulated as a manuscript among the population, the success of the early Latin histories of the Bulgarian Catholics depended on their printing in the Western publishing houses as a single means of dissemination; their target audience - however strange it might seem were not their subjugated fellow citizens who would not obviously understand a word in Latin since they barely had an access to any form of education. Thus it came about that two different literary traditions developed one after the other with no visible signs that the prior somehow inspired or indirectly affected the second one. The earliest examples of national historiography - apart from Historia Bulgarica and other writings of Petăr Bogdan Bakšič - included the Latin Relationes which the Bulgarian catholic bishops regularly sent to the Holy See in the seventeenth century. The accounts of Bakšič, Marco Bandulovič and Filip Stanislavovič (Stanislavov ${ }^{11}$ ), known through a published selection by B. Primov (1993), represented, strictly speaking, not a genuine historiography, but their lucid manner of storytelling and their resemblance to the ethnographic essay exceeded by far the limitations of the apostolic Relatio. The trouble, obviously, was that the Bulgarian population, although being a subject of these writings, could impossibly be their addressee as well. Unsurprisingly, the first literary attempts to create a comprehensive picture of the Bulgarian lands through the media of the Latin language did not leave any trace at all in the literature of the following two centuries. In contrast, the appearance of Istorija slavenobolgarskaja of Paisius of Hilendar had a huge effect on it, so that the national historiography reemerged on a new base, reconstructing national identity through a fervid defense of the vernacular. Bakšič's somewhat naïve conviction that Latin could be - at least at that particular moment - an efficient instrument for achieving the political goals of the Bulgarians, faded away with the suppression of the Chiprovtsi uprising in 1688. The last efforts to compose a history of Bulgaria in Latin are associated with the abovementioned history of Franjo Ksaver Pejačević and with the parish chronicles of the Catholic Bulgarians who migrated after the wars of the Ottoman Empire with Austria and Russia and settled down in Krayova, Budim, Alwinz, Deva, or Sremski Karlovtsi. Far from being just local records of the early history of the new settlements, Latin texts like Historia Parochiae O'Bessenyö - the parish chronicle of Old Beshenov, a Bulgarian settlement in Banat, evoked their Bulgarian origins and began with the foundation of the Bulgarian State as a distant event which eventually led to the establishment of their community. A distinctive feature of these Latin writings, composed on the territory of the Habsburg monarchy, was that they were strongly affected by the contemporary Hungarian and Austrian historiography, a fact which reflected sometimes upon their different interpretation of crucial points in the Balkan history, if compared with the later vernacular historiographical tradition. Consequently, the Latin historical works

11 Stanislavovič, who was a Bishop of the Nikopol Diocese between 1648 and 1663, founded a grammar school in Trănčovica, where introduction into the Latin language was taught, and translated from Latin into Bulgarian a still unpublished collection of liturgical texts (Cholov 1988: 229). 
written by Bulgarians in the seventeenth and the eighteenth centuries remained an isolated episode in the literary culture of the country.

\section{Conclusion}

The first translations of Latin authors in Bulgaria appeared considerably later than in other European countries, remaining for a long time based on intermediary Greek translations. Theatrum politicum of Ambrogio Marliani was the first Neo-Latin book, translated in Bulgarian by Sophronius of Vratsa, who apparently used a preceding Greek adaptation (1805), and it was only in 1873 that the first major direct translation - a fragment from Sallust's Coniuratio Catilinae - appeared in vernacular. In this way, the early modern literature in Bulgaria, while owing an immense debt to the Greek tradition, needed a whole century as to become emancipated from the translating techniques and tendencies of the neighbors. One could say the same about the poor tradition of Latinitas in the Bulgarian lands between the seventh and the nineteenth centuries: the authority of the Byzantine culture and of the Orthodox Church was far too great as to allow a parallel use of Latin in the political and diplomatic intercourse or to encourage the reception of Latin authors in the medieval Bulgarian literature. The post-classical fate of Latinitas, however, is not simply deficient or scarcely attested, but also insufficiently explored. The correspondence of the Bulgarian rulers with the Latin West and the Latin literary legacy of the Bulgarian Catholics are still waiting for being unearthed, published and translated; their full content, their literary models, and not in the last place, the intention of their authors are worthy of a thorough research.

\section{Bibliography}

Biller, Peter [\&] Anne Hudson (eds.) 1994. Heresy and Literacy, 1000-1530. Cambridge University Press.

Cholov, Peter 1988. Chiprovskoto vastanie 1688. [The Chiprovtsi Uprising 1688]. Sofija: Narodna prosveta.

Dimitrov, Bozhidar 2001. Petăr Bogdan Bakšev - bălgarski politik i istorik ot XVII vek. [Petăr Bogdan Bakšev - A Bulgarian politician and historian of the $17^{\text {th }}$ century]. Sofija: Nauka i izkustvo.

Dimitrov, Emil 1999. Dărzhava i tsărkva prez XIII vek. Prepiska na bălgarite s papa Inokentij III. [State and Church in the XIII ${ }^{\text {th }}$ century. The Correspondence of the Bulgarians with Pope Innocent III]. Sofija: Slavica.

Dondaine, Antoine 1950. „Le Tractatus de hereticis d'Anselme d'Alexandrie”, in: La hiérarchie cathare d'Italie, II. AFP (Archivum Fratrum Praedicatorum), 20. 307-324.

Dragova, Nadezhda 2005. Starobălgarskata kultura [The Old Bulgarian culture]. Sofija: LIK.

Dujčev, Ivan [\&] Borislav Primov [\&] Michail Vojnov (eds.) 1960. Fontes Latini Historiae Bulgaricae. T. II. Sofia: BAN.

_ 1965. Fontes Latini historiae Bulgaricae, T. III. Sofia: BAN. 
Fermendžin, Eusebius (ed.) 1887. Acta Bulgariae ecclesiastica ab a. 1565 usque ad a.1799. (Monumenta spectantia historiam Slavorum meridionalium XVIII). Zagrabiae: Academia sciantiarum et artium Slavorum meridionalium.

Gjuzelev, Vassil et al. (eds.) 1981. Fontes Latini historiae Bulgaricae, T. IV. Sofia: BAN.

Gjuzelev, Vassil 2009. Papstvoto i bălgarite prez Srednovekovieto. [The papacy and the Bulgarians during the Middle Ages]. Plovdiv: Bălgarsko istorichesko nasledstvo.

IJsewijn, Jozef 1990. Companion to Neo-Latin Studies. Part I. History and Diffusion of Neo-Latin Literature (Supplementa Humanistica Lovaniensia V). Leuven/ Louvain: Leuven University Press and Peeters Press.

Nikolova, Anna (ed.) 2002. Klassicheska literatura. (Prevodna receptsija na evropejskite literaturi, T. 3). [Classical literature. (Translations of the European Literatures, Vol. 3)]. Sofia: Marin Drinov.

Primov, Borislav (ed.) 1993. Dokumenti za katolicheskata dejnost v Balgaria prez XVII vek. [Records of the Catholic activity in Bulgaria during the XVII c.]. Sofia: St. Kliment Ohridski University Press.

Spasitelna kniga. Gratskijat original na Simeonovija sbornik 2008. [The Soul-Saving Book. The Greek Original of Simeon's Miscellany 2008]. Translated by Petya Yaneva and Serguey Ivanov. Sofia: Archetype. 